\title{
The dynamics change of fishpond land into settlement the east coast of Surabaya 2004-2017
}

\author{
Chahya Chairani $^{1}$, Ratna Saraswati ${ }^{2 *}$, Iqbal Putut Ash Shidiq ${ }^{3}$ \\ ${ }^{1}$ Departemen Geografi, Universitas Of Indonesia, \\ ${ }^{2}$ Departemen Geografi, Universitas Of Indonesia \\ ${ }^{3}$ Departemen Geografi, Universitas Of Indonesia
}

\begin{abstract}
Surabaya rapidly developed to the east region which grew the formal/non-formal settlement in Pamurbaya. This area is dominated by fishpond that is converted into settlement area. This research aims to observe the dynamic change of fishpond which is already converted into settlement area in the east coast of Surabaya, during 2004-2017. This research applies landsat image $7 \mathrm{ETM}+$ and landsat 8 OLI with overlay method which is analyzed descriptively. During 2004-2017, the settlement area had been developing for $218,296 \mathrm{Ha}$ or $88 \%$ and during the same years, the fishpond had been reducing for 531,639 Ha or $24 \%$, this reduction can change into mangrove or settlement area. During 13 years, the change of fishpond into settlement area is $15 \%$. The research area which experienced the change is the fishpond of Kejawan Putih (24\%), Medokan Ayu area (17\%), and Keputih area $(16 \%)$.
\end{abstract}

Keywords: Changes; Settlement; Fishpond.

\section{Introduction}

Urban areas continue to do development and development in some sectors, such as; infrakstruktur development, education, housing up to the industry. Vigorous development was done one of them caused by rapid economic growth in the city [1]. The factors of development and growth that works on a city can develop and grow the city in a certain direction. There are three main factors that determine patterns of development and the growth of cities: 1). The human factor, that concerns the facet facet of development of city residents either due to birth or due to migration to the cities. In terms of development-in terms of labor, the development of social status and the development of knowledge and technology capabilities. 2). Human activity Factors, namely regarding work activities facet facet, functional activities, activities of the economy of the city and the activities of regional relations. 3). The factor pattern of movement, i.e. as a result of the developments caused by these two factors development of population are accompanied by the development of the functions of its activities will be demanded of the patterns of transportation between the activities of the centres [2].

Development for the city of Surabaya aim to meet the needs of the growing population, as for the related needs of the construction of residences, office buildings, and a means of education. So Surabaya developing to the East due to the existence of a concentration of educational institutions, the development of residential, bulk and ease of access from the Centre towards the East. The development seen from the large number of land settlements, such as waking up offices and others in the area east of Surabaya. One of the factors that cause the rapid development is an easy transportation access, road MERR (Midle East Ring Road) is one of the access of transport simplify Community East of Surabaya, the shopping center is a fairly complete and the large number of well-known universities in surabaya East that caused appears settlements. The eastern part of surabaya also called with East Coast surabaya (Pamurbaya). Use of other land that dominates the area east of Surabaya is farmed. Fishponds scattered from Mulyorejo to Gunung Anyar district, overall land area of fishponds in the area east of Surabaya, covering an area of 2,287.748 Ha. Fishponds existed before the year 2000 in Pamurbaya. In Pamurbaya there is dynamics change landuse from 2004-2017, that changes fishponds land into settlements. In 2004 pamurbaya had a few of settlements, but domination by vacant land and fishponds. In 2017, the settlement already developing in Pamurbaya. The settlements are a large and luxurious cluster, and some of them in the course of construction.

The aim of this research is to know the dynamics changes of fishponds land into settlements land in Pamurbaya during 2004-2017. To know the dynamics changes of fishponds land became a settlement land, need to use remote sensing technology. Spatial data and information that can be 
obtained by utilizing the technology of remote sensing [3]. Remote sensing is defined as the measurement or retrieval of information from some of the properties of an object or phenomenon, using recording device that physically contact does not occur directly or intersect an object or phenomenon is examined [4]. The use of remote sensing technology for the mapping and monitoring of the resources to be useful to a broad coverage area and spatial information [5]. Sensor ETM + is the development of TM sensor with the addition of a panchromatic channel 11 designed to have spatial resolution of $15 \times 15$ meters in addition is also designed to be able to record a six-channel multispectral imagery by using the wave length look, infrared, and infrared short with a resolution of 30 meters [6]. ETM + sensor not to different with sensor TM. The difference is on the number of bands that they have. On sensor TM 7 band (band 1, 2, 3, 4, 5, $6,7)$ while the senson ETM + there are 8 bands (bands 1, 2, 3, 4, 5, 6, 7, 8) [7]. Landsat 8 OLI has 1 canal near infrared and has 7 canal appear, with a spatial resolution of 30 meters. Landsat 8 OLI had canals that resembles a spectral sensor ETM + (Enhanced Thermal Mapper plus) from Landsat-7, but it had a OIL sensor imagers canals a new IE: Canal-1:443 nm for aerosols the coastline and the Canal 9:1375 nm for detection of cirrus, but does not have a thermal infrared channel [8].

In this study using landsat 8 OLI imagery for 2017 and landsat 7 ETM + imagery 2004. The landsat imagery was used to identify the changes of fishponds lands to be a settlement land in Pamurbaya. The methods used in this research is the overlay method, i.e. overlay the settlement and the fishpond.

\section{Material and Methods}

Location : The city of Surabaya is located at $7^{\circ} 9^{\prime}$ $07^{\circ} 21^{\prime}$ South and $112^{\circ} 36^{\prime}-112^{\circ} 54^{\prime}$ East.An area of the city of Surabaya is $52,087 \mathrm{Ha}$, with a land area of $33,048 \mathrm{Ha}$ or $63.45 \%$ and the rest around 19,039 $\mathrm{Ha}$ or $36.55 \%$ marine region is maintained by the Government of the city of Surabaya [9]. The city of Surabaya is divided into 31 districts and 154 villages. The total population of the city of Surabaya on the based on Badan Perencanaan Pembangunan Kota Surabaya (BAPPEKO) year 2015 - 2017 overall amounted to $3,336,226$ inhabitants. Pamurbaya is located in Surabaya, East Java. Pamurbaya is located at coordinates $7^{\circ} 16^{\prime} 03^{\prime \prime} \mathrm{S}-112^{\circ} 50^{\prime} 31^{\prime \prime} \mathrm{E}$ and East Coast Surabaya extends from Kecamatan Mulyorejo until Gunung Anyar.

Data : In this study use landsat 7 ETM + imagery and landsat 8 OLI imagery. This landsat image downloaded from the USGS with path/row 118/65. Before used the landsat imagery, needs to be processed. First step is atmospheric correction, to fix the value of the pixel on satellite imagery as well as radiometric errors due to enhance image visualization [10] and geometric correction to fix the position of the object in order to be at exactly the right place.
Then Layer Stacking to the process of making multi image on the band, i.e. by combining images from separate bands into a single file. This process is very important to perform further image processing such as digital classification process requires a multi band image. Sharppening the imagery to aims to improve the quality of visual imagery so make it easier in the process of interpretation. Do the classification to get land cover using supervised method. The result of classification image must be doing test accuracy, to find out the truth of the result.

To analyze this research, the research area will be divided into 6 regions. The division is based on the nearest distance between settlement and fishpond that constrained by the street. The 6 area are Kalisari, Kejawan Putih Tambak, Keputih, Wonorejo, Medokan Ayu and Gunung Anyar Tambak. The analysis that used in this study is overlay method, so it can see the change over function from fishpond land to settlement and analyze with the spatial descriptive analysis.

\section{The Result}

\subsection{The Change Of Settlement $2004-2017$}

Settlement development of extensive deforestation every year due to the needs of human habitation. The settlements in Pamurbaya every years have elevated the spacious. This happens because the rapid development in the city of Surabaya to Pamurbaya.

In 2004, in Pamurbaya still dominated by empty land, fishponds and mangrove. In 2004, Pamurbaya had total area of settlement 44.965 Ha. Kalisari had width of settlement 4,43 Ha, Kejawan Putih Tambak had width of settlement 14,43 Ha, Keputih had width of settlement 3,31 Ha, Wonorejo and Medokan Ayu had width of settlement $0 \mathrm{Ha}$, and Gunung Anyar Tambak had width of settlement 22,79 Ha. However in 2017 settlement had appear in Pamurbaya (Fig.1). Total area of settlement in Pamurbaya 265,68 Ha, with Kalisari had width of settlement 55,88 Ha, Kejawan Putih Tambak had width of settlement $27,38 \mathrm{Ha}$, Keputih had width of settlement 34,21 Ha, Wonorejo had width of settlement 20,5 Ha, Medokan Ayu had width of settlement 37,15 Ha, and Gunung Anyar Tambak had width of settlement 90,54 Ha.

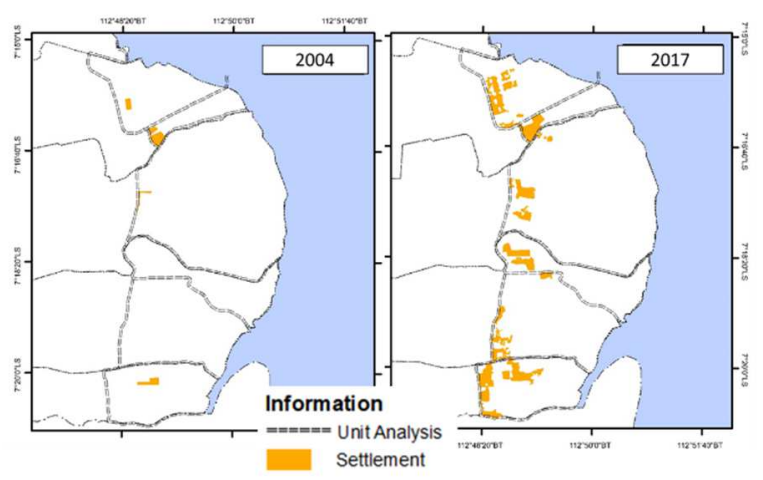

Fig.1: Settlement in Pamurbaya in 2004 and 2017. 
During the year 2004 - 2017 settlement area suffered a slight reduction. There was a decreased on settlement area for $5.39 \mathrm{Ha}$ or $2 \%$, increased area for $218.3 \mathrm{Ha}$ or $88 \%$ and unchanged area $2.562 \mathrm{Ha}$ or $10 \%$. The most increased area of settlement is Gunung Anyar Tambak with 62.488 Ha. In figure.2, the pink one is the increased area, the blue one is the decreased area and the yellow one is the unchanged area(Fig.2).

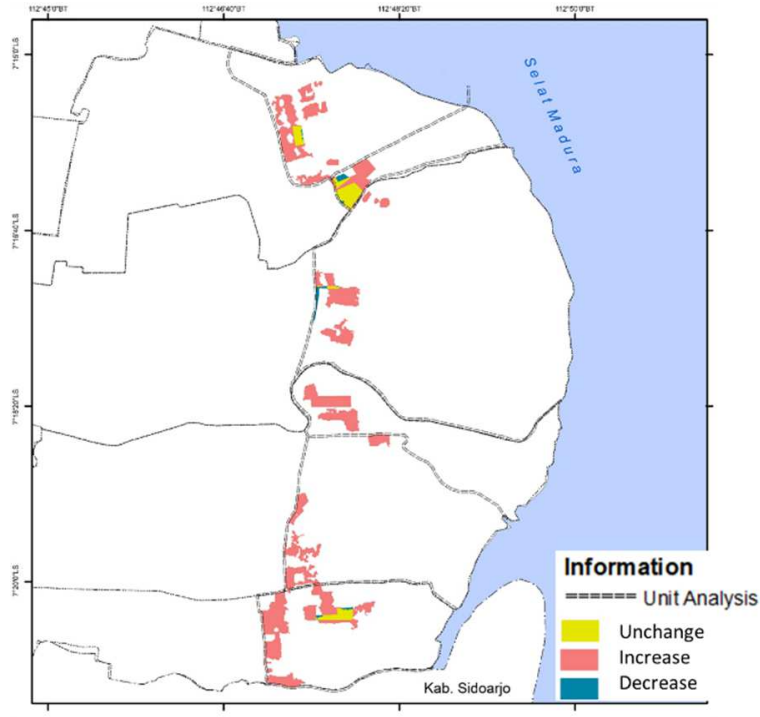

Fig.2 : The Change Of Settlement During 2004-2017

\subsection{The Change Of Fishpond $2004-2017$}

Fishponds are the most dominant land in East Coast Surabaya (Pamurbaya). Fishponds in Pamubaya already existed before 2000, they spread along East Coast Surabaya until Sidoarjo. Fishpond in Pamurbaya has an important role in people's livelihoods, people who live in Pamurbaya mostly cultivating whitefish and shrimp.

In 2004, fishpond area had total area $1.932,645 \mathrm{Ha}$. Kalisari had width of fishpond area 160,463 Ha, Kejawan Putih Tambak had width of fishpond area 79,508 Ha, Keputih had width of fishpond area 1.054,889 Ha, Wonorejo had width of fishpond area 1.66,769 Ha, Medokan Ayu had width of fishpond area 291,473 Ha, and Gunung Anyar Tambak had width of fishpond area $179,543 \mathrm{Ha}$. In 2017, total area of fishpond area 1.685,275 Ha. Kalisari had width of fishpond area 123,696 Ha, Kejawan Putih Tambak had width of fishpond area $52,759 \mathrm{Ha}$, Keputih had width of fishpond area $860,962 \mathrm{Ha}$, Wonorejo had width of fishpond area 146,774 Ha, Medokan Ayu had width of fishpond area 343,934 Ha, and Gunung Anyar Tambak had width of fishpond area $157,150 \mathrm{Ha}$. Figure. 3 is a fishpond area in 2004 and 2017.

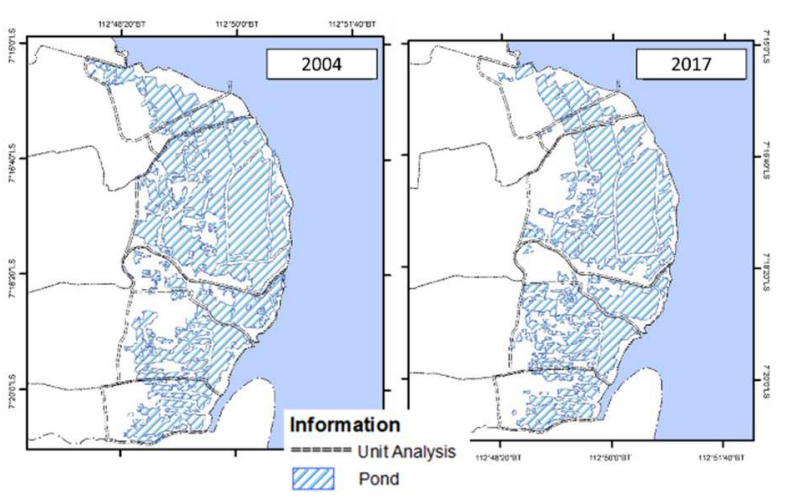

Fig.3: Fishponds in Pamurbaya in 2004 and 2017.

During the year 2004 until 2017, there was a decline changes width of fishponds area. Decreased fishponds area for $531.639 \mathrm{Ha}$ or $24 \%$, increased area for $280.695 \mathrm{Ha}$ or $13 \%$ and unchanged area for $1,398.724$ Ha or $63 \%$ (Fig.4).

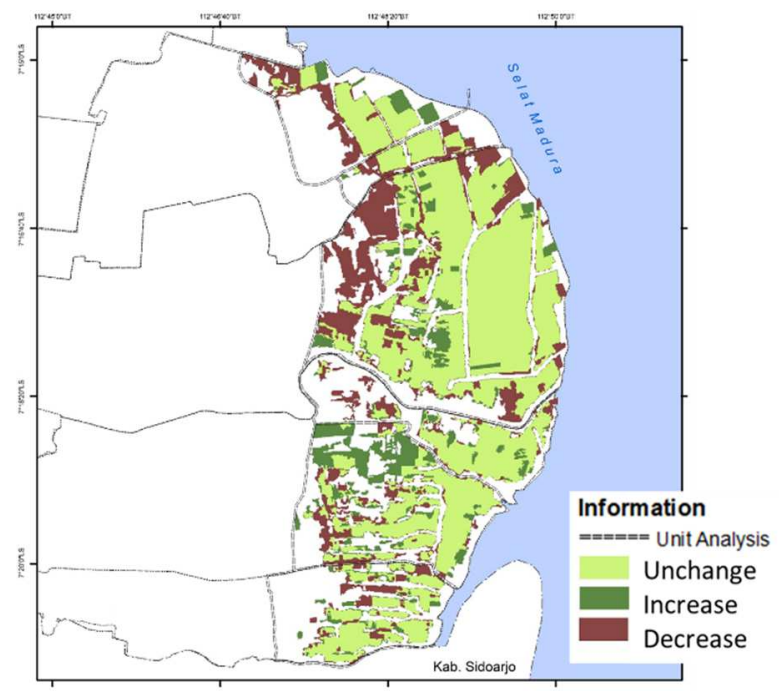

3.3 Change of Fishpond Land Into Settlement

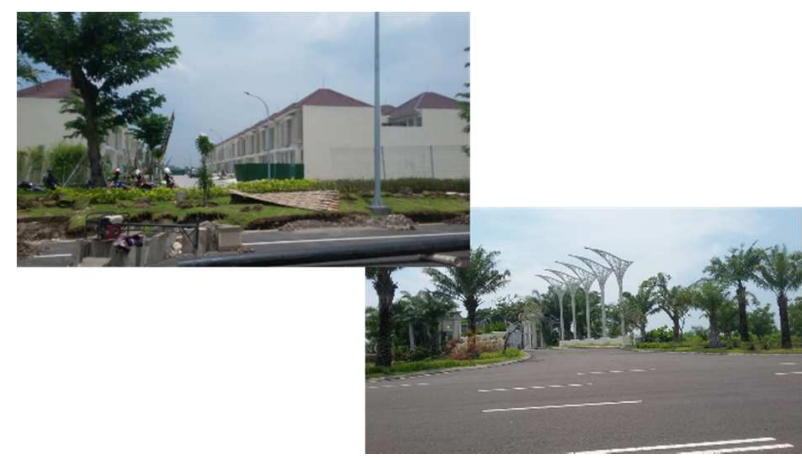

Fig.5: Settlement in Kalisari

During 13 years, there was a changed fishpond land into settlement in Pamurbaya. For settlemant area in each years of the research having increase width. Formal housing started growing like Pakuwon City, Bumi Marina Mas, Sukolilo Park Regency, Sukolilo Dian Regency, Green Semanggi Mangrove, Green Lake and Pantai Keputih Permai. Figure.5 is the big cluster settlement in Kalisari, they nearby the fishpond land. 
Table.1 : Changed fishpond land into settlement in each unit analysis.

\begin{tabular}{|l|c|}
\hline \multicolumn{1}{|c|}{ Unit Analysis } & $\begin{array}{c}\text { Fishpond } \rightarrow \\
\text { Settlement }\end{array}$ \\
\hline Kalisari & 2,9 \\
\hline Kajawan Putih Tambak & 5,61 \\
\hline Keputih & 22,22 \\
\hline Wonorejo & 6,54 \\
\hline Medokan Ayu & 5,61 \\
\hline Gunung Anyar Tambak & 4,54 \\
\hline Total & $\mathbf{4 7 , 4 2}$ \\
\hline
\end{tabular}

Fishpond land that turned into a settlement land had total width for 47,42 Ha during 2004 - 2017. In each unit analysis there was a changed fishpond land into a settlement (Table.1). In Kalisari had width of the changed land 2,9 Ha, Kejawan Putih Tambak had width 5,61 Ha, Keputih had width 22,22 Ha, Wonorejo had width 6,54 Ha, Medokan Ayu had width 5,61 Ha and Gunung Anyar Tambak 4,54 Ha. Keputih had the most width changes fishpond land into a settlement 22,22 Ha.

\section{Conclusion}

In 2004, Pamurbaya had total area of settlement $44.965 \mathrm{Ha}$ and for 2017 total area 265,68 Ha. In 2004, fishpond area had total area 1.932,645 $\mathrm{Ha}$ and in 2017, total area of fishpond 1.685,275 Ha. for 13 years, the vast increased in settlement area and followed the vast decreased in fishpond land.

Surabaya has experiencing rapid development that cause the settlement concentrate on the center of the city spread eastwards surabaya. In 2004, in Pamurbaya still dominated by empty land, fishponds and mangrove but in 2017 settlement had appear in Pamurbaya. Fishponds are the most dominant land in East Coast Surabaya (Pamurbaya). Because there was limited space to bulit up the settlement, so they change the function of fishpond land into a settlement land. There was a changed fishpond land into settlement in Pamurbaya. For settlemant area in each years of the research having increase width. Fishpond land that turned into a settlement land had total width for 47,42 Ha during $2004-2017$. Keputih had the most

Along with the expansion of the settlements on East Coast Surabaya, need to note in realizing lowcarbon development/low-carbon society in the development process. The trick is to make environmentally friendly settlements, building of open green space in each block. The construction of settlements on the East Coast surabaya should have barrier between the fishpond and the area of mangrove, so as not to disturb the fishpond and damaging the ecosystem of mangroves near the fishpond, because it relies on mangrove plants along the East Coast surabaya, and mangrove plants can also realize a low carbon environment efforts.

\section{Acknowledgement}

The author would like to thank Directorate of Research and Community Service (DRPM) Universitas Indonesia, which has supported this research in HIBAH PITTA UI Year 2018 with contact number 2299/UN2.R3.1/HKP.05.00/2018.

\section{Reference}

1. Wresniwara, M.I.H. Reim Pertumbuhan Kota : Studi Pembangunan di Kecamatan Gunung Anyar. Jurnal Politik Muda, Vol. 6, No. 2, April - Juli 2017, 156 - 162. (2017)

2. Sujarto,D. Faktor-Faktor Perkembangan Kota Perencanaan Pembangunan Kota, Departemen Planologi Fakultas Teknik Sipil dan Perencanaan Institut Teknologi Bandung. Bandung. (1989)

3. Damayanti, I.R. Patwati, E. Wijaya, N.I. Perubahan Luas dan Kerapatan Ekosistem Mangrove di Kawasan Pantai Timur Surabaya. Fakultas Teknik dan Ilmu Kelautan Universitas Hang Tuah. Surabaya. (2017)

4. Lillesand, T.M., and Kiefer, R.W. Penginderaan Jauh dan Interpretasi Citra, Terjemahan, Gadjah Mada University Press, Yogyakarta. (1999)

5. Saraswati, Ratna dan Rahardjo, Sugeng. Mapping The Coastal Zone By Integrating Radar And Optical Data In The South Bali Island. Proceeding 19th International Cartographyic Conference. 11th General Assembly of ICA Touch The Past. Visualiza The Future. Ottawa ICA 1999, Canada. (1999)

6. Purwadhi, F.S.H. Interpretasi Citra Digital. PT. Grasindo. Jakarta. (2001)

7. Maercello, Hansel. Perbuhan mangrove di wilayah pesisisr Indramayu. Departemen Geografi, Fakultas Matematika Ilmu Pengetahuan Alam, Universitas Indonesia, Depok. (2012)

8. Sitanggang, Gokmaria. Kajian Pemanfaatan Satelit Masa Depan: Sistem Penginderaan Jauh Satelit LDCM (Landsat-8). Berita Dirgantara Vol. 11 No. 2 Juni 2010:47-58. Peneliti Bidang Bangfatja, LAPAN. (2010)

9. Dinas Pertanian Kota Surabaya. Profil Perikanan Kota Surabaya Tahun 2012. Bidang Perikanan dan Kelautan. (2013)

10. Ardiansyah. Pengolahan Citra Penginderaan Jauh. Jakarta: PT. LABSIG INDERAJA ISLIM. (2015) 